\title{
KEWENANGAN PENGELOLAAN PEMBANGUNAN KAWASAN PERBATASAN KALIMANTAN BARAT - SARAWAK (Studi Dari Aspek UU No. 43 Tahun 2008 Tentang Wilayah Negara)
}

Oleh :

M. Syafei

Dosen Fakultas Hukum Universitas Tanjungpura Pontianak Kalimantan Barat

\begin{abstract}
ABSTRAK
Menjadikan kawasan perbatasan sebagai beranda depan negara, merupakan visi utama pemerintah pusat dan daerah untuk mewujudkan kesejahteraan rakyat di kawasan perbatasan Indonesia dengan negara tetangga. Karena itu, dengan terbentuknya Undang-Undang Nomor 43 Tahun 2008 tentang Wilayah Negara dan Peraturan Presiden Nomor 12 Tahun 2010 tentang Badan Nasional Pengelola Perbatasan, maka seharusnya tidak ada lagi alasan bahwa terabaikannya pelaksanaan pembangunan kawasan karena tidak memiliki payung hukum. Sebab, kewenangan pemerintah, pemerintah provinsi, pemerintah kabupaten, dan Badan Pengelola sudah diatur cukup jelas. Persoalannya, apakah dengan kewenangan tersebut, akan dapat dilaksanakan secara efektif, efisien dan mencapai target yang diharapkan? Kesemuanya itu sangat tergantung pada fakta kongkret implementasi Rencana Induk dan Rencana Aksinya.
\end{abstract}

Kata Kunci: Kawasan Perbatasan dan Kesejahteraan Rakyat.

\section{PENDAHULUAN}

Sebagaimana diketahui, secara geografis Negara Indonesia memiliki perbatasan darat internasional dengan Negara Malaysia, PNG, dan Timor Leste. Perbatasan darat tersebut berada di provinsi Kalimantan Barat, Kalimantan Timur, Papua, dan Nusa Tenggara Timur. Sedangkan di laut, perairan Indonesia berbatasan kedaulatan dan atau hak berdaulat dengan 10 negara tetangga yaitu : Malaysia, PNG, Timor Leste, India, Thailand, Vietnam, Singapura, Filipina, Palau, dan Australia. ${ }^{1}$

Panjang perbatasan darat Indonesia dengan Malaysia kurang lebih 2.004 kilometer yang terbentang dari Tanjung Datu di sebelah barat hingga ke pantai timur pulau Sebatik di sebelah Timur. Garis batas ini melintasi 8 (delapan) kabupaten di dua provinsi, yaitu : Kabupaten Sanggau, Sambas, Sintang, Kapuas Hulu, dan Bengkayang di Provinsi Kalimantan Barat dan Kabupaten Malinau, Kutai Barat, dan Nunukan di Kalimantan Timur. Panjang garis perbatasan darat di Provinsi Kalimantan Barat adalah 966 kilometer yang memisahkan wilayah NKRI dengan wilalayah Sarawak, Malaysia.

1 Rencana Induk Pengelolaan Batas Wilayah Negara Dan Kawasan Perbatasan, 2011-2014, Kementerian Perencanaan Pembangunan Nasional/Badan Perencanaan Pembangunan Nasional, PT.Pillar Pusaka Inti, Jakarta, Desember, 2010, Bab2/1. 
Sedangkan garis perbatasan darat di Provinsi Kalimantan Timur sepanjang 1.038 kilometer yang memisahkan wilayah NKRI dengan negara bagian Sabah dan Serawak, Malaysia. $^{2}$

Dasar hukum delimitasi batas darat Pulau Kalimantan dan Pulau Sebatik dengan Malaysia mengacu pada perjanjian batas antara Pemerintah Inggris dan Pemerintah Hindia Belanda ialah Traktat 1891, Konvensi 1915 dan 1928 serta MOU batas darat Indonesia dengan Malaysia tahun 1973-2006. Sedangkan penegasan batas (demarkasi) secara bersama diantara kedua negara telah dimulai sejak tahun 1973, dan sampai tahun 2009 telah dihasilkan tugu batas sebanyak 19.328 buah lengkap dengan koordinatnya. Delimitasi batas darat Republik Indonesia dengan Malaysia tersebut sebagian besar berupa watershed (punggung gunung/bukit, atau garis pemisah air), walaupun sudah selesai, tetapi secara demarkasi masih tersisa 9 (sembilan) titik bermasalah (outstanding boundary problems). Kemudian mengenai penuntasan permasalahan perbatasan darat Republik Indonesia dengan Malaysia, selama ini sudah ditangani oleh tiga lembaga yaitu: (1) General Border Commitee (GBC) RI-Malaysia dikoordinasikan oleh Kementerian Pertahanan; (2) Joint Commission Meeting (JCM) RI-Malaysia, yang dikoordinasikan oleh Kementerian Luar Negeri; dan (3) Sub Komisi Teknis Survey dan Demarkasi yang dikoordinasikan oleh Kementerian Dalam Negeri. Sedangkan untuk penanganan masalah Outstanding Border Poblem (OBP), telah dibentuk Kelompok Kerja Bersama (Joint Working Group) antara kedua negara. Untuk tahap awal telah disepakati untuk dibahas 5 (lima) permasalahan di sektor Timur (Kalimantan TimurSabah). ${ }^{3}$

\section{B. ISU STRATEGIS}

Secara garis besar isu strategis dalam pengelolaan batas wilayah negara dan kawasan perbatasan dikelompokkan dalam 5 (lima) aspek, yaitu: (1) Aspek Penetapan dan Penegasan Batas; (2) Aspek Pertahanan, Keamanan dan Hukum; (3) Aspek Ekonomi Kawasan; (4) Aspek Sosial Dasar; dan (5) Aspek Kelembagaan. ${ }^{4}$

Keseluruhan aspek yang menjadi isu strategis tersebut, menurut pendapat penulis hakikatnya dapat diintegrasikan ke dalam permasalahan inti, masih lemahnya ketahanan nasional Indonesia di kawasan perbatasan. ${ }^{5}$ Kenyataan ini dapat dicermati dari beberapa indikator, antara lain sebagai berikut :

1. Sebagian besar wilayah perbatasan darat di Indonesia memang masih merupakan daerah tertinggal disebabkan terbatasnya sarana dan prasarana ekonomi, sosial, budaya dan sarana pendukung lainnya sehingga kondisi sebagian besar masyarakatnya berada dalam kondisi miskin. Di lain pihak, negara tetangga (Malaysia) telah membangun pusat-pusat pertumbuhan dan koridor perbatasannya melalui berbagai kegiatan ekonomi dan perdagangan yang telah memberikan keuntungan bagi pemerintah maupun masyarakatnya. Mengakibatkan tingginya

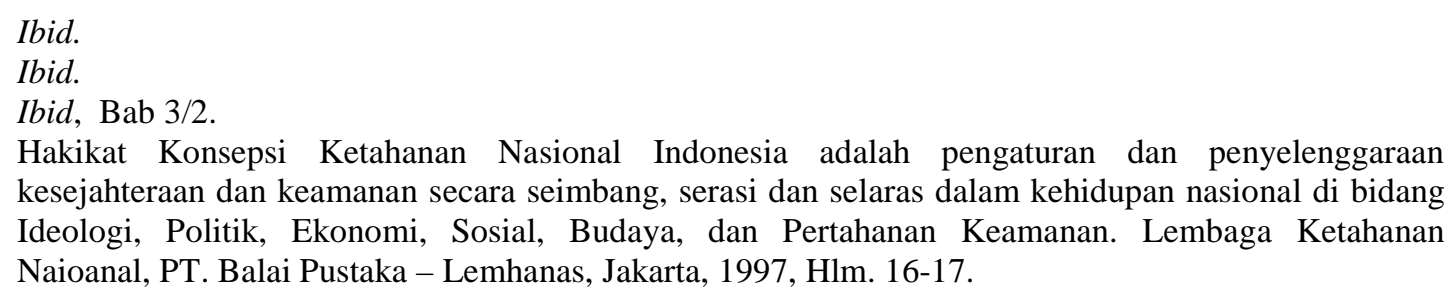
kesejahteraan dan keamanan secara seimbang, serasi dan selaras dalam kehidupan nasional di bidang Ideologi, Politik, Ekonomi, Sosial, Budaya, dan Pertahanan Keamanan. Lembaga Ketahanan Naioanal, PT. Balai Pustaka - Lemhanas, Jakarta, 1997, Hlm. 16-17. 
tingkat ketergantungan masyarakat perbatasan terhadap negara tetangga dan menimbulkan berbagai kegiatan illegal maupun eksploitasi sumber daya alam yang tidak terkendali. ${ }^{6}$

2. Kaburnya garis perbatasan wilayah negara akibat rusaknya patok-patok di perbatasan Kalimantan Barat dan Kalimantan Timur menyebabkan sekitar 200 hektare hutan wilayah Republik Indonesia berpindah masuk menjadi wilayah Malaysia.. $^{7}$

3. Banyaknya pelanggaran batas yang dilakukan WNI ataupun WNA yang diakibatkan oleh tidak jelasnya batas negara. ${ }^{8}$

4. Penyelundupan manusia, perdagangan obat terlarang, penyelundupan senjata ringan, penyebaran aksi terorisme, dan kejahatan internasional lainnya yang melampaui batas kedaulatan nasional. Terorisme, separatisme, dan kejahatan trans-nasional yang lain dimungkinkan saling berkaitan erat dalam memanfaatkan atau mengeksploitasi jalur-jalur laut di wilayah perairan Indonesia, sehingga mereka bisa bergerak dengan bebas untuk memasuki Indonesia.. ${ }^{9}$

5. Maraknya kasus-kasus pencurian ikan oleh nelayan-nelayan lokal maupun nelayan asing. Dari aspek lingkungan, pengelolaan sumberdaya ikan yang tidak bertanggung jawab ini akan menghambat kemajuan sektor perikanan tangkap yang berkelanjutan. ${ }^{10}$

Khusus kondisi Daerah Kalimantan Barat yang berbatasan dengan Negara Bagian Sarawak - Malaysia Timur, kecenderungan yang cukup merawankan dilihat dari aspek geografi, kondisi penduduk dan sumber daya alam :

1. Terdapat 5 wilayah kabupaten, 15 kecamatan, 98 desa, dengan luas $\pm 23.741 \mathrm{~km} 2$, yang berbatasan langsung dengan wilayah Negara bagian Sarawak Malaysia, dengan kepadatan penduduk rata-rata 8 orang / km2

2. Terdapat sekitar 50 jalan setapak yang menghubungkan 55 desa di Kalbar dengan 32 kampung di Sarawak, yang disepakati 16 PLB di Kalbar dan 10 di Sarawak (2002).

3. Pos Pemeriksaan Lintas Batas (PPLB) yang resmi Entikong, menyusul PPLB Nanga Badau (operasional 2006) dan PPLB Aruk (operasional 2007).

4. Kesenjangan Tingkat Kesejahteraan Masyarakat berkisar antara 400 US\$ Vs 4.000 US\$.

5. Belum optimalnya koordinasi antar instansi (Pusat - Daerah) dalam penanganan wilayah perbatasan.

6. Keterbatasan prasarana wilayah (transportasi, listrik, air bersih, dan telekomunikasi) dan sarana sosial (pendidikan dan kesehatan) sehingga diklasifikasikan sebagai wilayah tertinggal. ${ }^{11}$

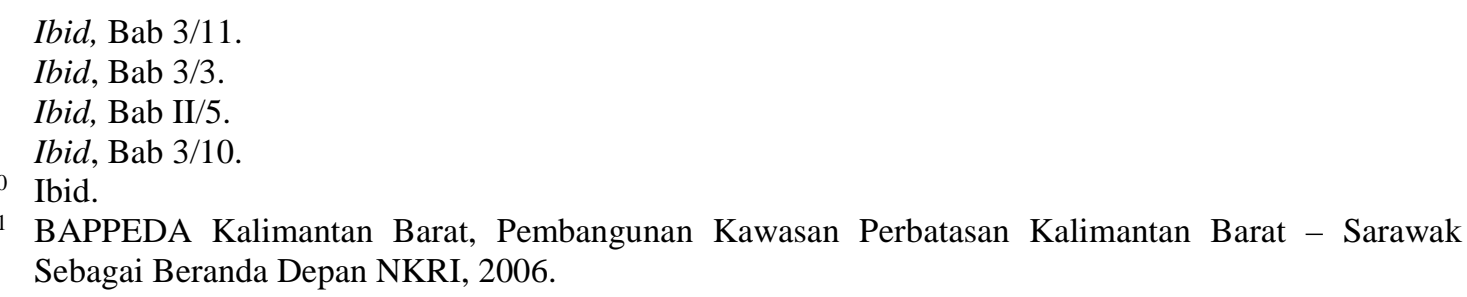




\section{PEMBAHASAN}

\section{A. Sumber Kewenangan}

Negara adalah organisasi kekuasaan yang menghimpun satuan masyarakat manusia dalam suatu wilayah tertentu sebagai suatu bangsa, ${ }^{12}$ memiliki pemerintahan berdaulat dan diakui eksistensinya oleh suatu Negara/Bangsa-bangsa lainnya dalam pergaulan masyarakat Internasional. ${ }^{13}$ Sebagai organisasi kekuasaan, maka di dalam organisasi Negara ditentukan perangkat-perangkat, organ-organ, lembaga-lembaga, atau alat kelengkapan Negara yang menurut teori Trias Politica terdiri dari : Lembaga Legislatif, Lembaga Eksekutif dan Lembaga Yudikatif. Ketiga lembaga kenegaraan tersebut sifatnya sangat fundamental, maka harus selalu ada di dalam suatu Negara Hukum yang bersifat Demokratis. Sedangkan eksistensi lembaga-lembaga lainnya dapat saja ditentukan sesuai dasar filosofi, bentuk negara dan sistem pemerintahan yang dianut oleh suatu negara.

Meskipun berdasarkan amandemen UUD 1945 penjelasan UUD 1945 telah dihapus, namun pada amandemen ketiga tetap menormatifkan "Negara Indonesia adalah Negara Hukum". ${ }^{14}$ Makna terdalamnya "Negara dan segenap rakyat tunduk pada hukum". Dengan kata lain, mewajibkan Negara dalam segala tindakannya baik ke dalam maupun di luar yurisdiksinya haruslah senantiasa berdasarkan atas hukum. Pokok pikiran tersebut menjadi norma fundamental bagi pembentukan sistem hukum nasional di tingkat pusat maupun daerah untuk mengoperasionalisasikan penyelenggaraan pemerintahan dan pembangunan nasional ke seluruh pelosok tanah air, guna mwujudkan tujuan negara yang dicitakan, sebagaimana termaktub dalam Pembukaan UUD 1945, yang menyatakan Negara : "melindungi segenap bangsa Indonesia dan seluruh tumpah darah Indonesia, memajukan kesejahteraan umum, mencerdaskan kehidupan bangsa, ikut melaksanakan ketertiban dunia, dan mewujudkan suatu Keadilan sosial bagi seluruh rakyat Indonesia." 15

Keempat tujuan Negara itu, memang sudah diupayakan mewujud-kannya melalui penyelenggaraan pemerintahan dan pembagunan oleh pemerintah orde lama, orde baru dan orde reformasi sekarang ini. Namun hasil-hasilnya, tetap saja dirasakan masih belum memuaskan. Terutama pembangunan di kawasan perbatasan, yang sampai kini dinilai masih menjadi daerah tertinggal dari aspek pembangunan infra dan supra struktur ekonomi, sosial, maupun budaya, sehingga berpengaruh negatif terhadap ketahanan nasional Negara Kesatuan Republik Indonesia.

Pengaturan kewenangan tidak lepas kaitannya dengan teori kedaulatan yang menurut Jeans Bodin, merupakan kekuasaan tertinggi dalam suatu negara yang bersifat bulat, asli, tidak dapat dibagi-bagi, dan berlangsung terus-menerus tanpa terputus-

12 Tanpa dibatasi oleh perbedaan suku, agama, ras, warna kulit, adat istiadat, dan atau nilai-nilai obyektif alamiah . Nilai-nilai Obyektif Alamiah: Daratan, Lautan dan Udara dengan segala bentuk kekayaan sumberdaya alam yang terkandung di dalamnya.

13 Pengakuan eksistensi suatu Negara yang berdaulat oleh Negara/bangsa-bangsa lainnya dalam pergaulan masyarakat Internasional, sangat penting artinya dari segi hukum Internasional, terutama untuk menjalankan kedaulatan Negara tersebut ke luar yang akan bersentuhan dengan kedaulatan Negara lainnya.

14 Bab I Pasal 1 (3) Amandemen UUD 1945.

15 Selengkapnya lihat Pembukaan UUD 1945. 
putus. Karena itu, meskipun pemerintah dan Kepala Negara dapat berganti-ganti, tetapi negara dengan kedaulatannya tetap ada dan berlangsung terus tanpa terputus. ${ }^{16}$ Demikian pula menurut Harold J. Laski bahwa: "The modern state is a sovereign state. It is, therefore, independent in the face of other communities. It may infuse its will towards them with a substance which need not be affected by the will of any external power. It is, moreover, internally supreme over the territory that it control". ${ }^{17}$ Dan dalam konteks terbentuknya negara-negara konstitusional yang demokratis, terdapat tiga macam kedaulatan yang berkohesif (melarut), yaitu: kedaulatan rakyat, kedaulatan hukum dan kedaulatan Negara.

Teori kedaulatan rakyat berbasis pada pemikiran Jean Jacques Rousseau yang memposisikan rakyat sebagai pemegang kedaulatan tertinggi di dalam suatu Negara. Tanpa rakyat, negara dan pemerintahan tidak mungkin ada. Sebab, adanya rakyat merupakan salah satu persyaratan pokok dari adanya Negara. Konsep kedaulatan rakyat juga lazim diidentikkan dengan konsep demokrasi, yang dimaknakan sebagai pemerintahan dari, oleh dan untuk rakyat. Karena itu, kehendak Negara haruslah berbasis pada kehendak rakyat. ${ }^{18}$

Sungguhpun demikian, agar kehendak rakyat tidak memunculkan kekuasaan (diktator) mayoritas, dan pemerintahan negara dapat dilaksanakan secara tertib, teratur, demokratis, serta berkeadilan, maka penyelenggaraan kedaulatan rakyat perlu diatur berdasarkan atas hukum yang diformulasikan ke dalam konstitusi atau hukum dasar tertulis dari suatu negara. Pengaturan inilah yang kemudian melahirkan paham negara hukum atau konstitusionalisme, yang menempatkan hukum sebagai ketentuan yang berdaulat atau supreme dalam penyelenggaraan pemerintahan dan pembangunan.

Terkait dengan konsep konstitusionalisme di atas, maka pemahaman terhadap Negara Hukum Indonesia sebagaimana dinormatifkan berdasarkan Pasal 1 ayat (3) amandemen UUD NRI 1945, hakikatnya memiliki karakteristik pokok sebagai berikut:

1. Berfungsi untuk mewujudkan Tujuan Negara sebagaimana tercantum dalam Alinea Ke IV Pembukaan UUD NRI 1945;

2. Menempatkan Pancasila sebagai dasar negara, falsafah hidup bangsa dan sumber dari segala sumber hukum negara $;{ }^{19}$

3. Memposisikan Undang-Undang Dasar Negara Republik Indonesia Tahun 1945 sebagai landasan konstitusional penyelenggaraan pemerintahan negara dan hukum dasar pembentukan Peraturan Perundang-undangan; ${ }^{20}$

4. Kedaulatan berada di tangan rakyat dan dilaksanakan menurut Undang-Undang Dasar, yang mewajibkan penetapan kebijakan negara, penyelenggaraan pemerintahan dan pembangunan nasional dilakukan secara demokratis $;^{21}$

16 Tudor Jones, Modern Political Thinkers And Ideas An Historical Introduction. London: Routledge, 2002, P. 3. Lihat pula J.H. Price, Comperative Government, London: Hutchinson \& Co, 1975. P. 26; Mark O. Dickerson and Thomas Flanagan (1988), An Introduction to government and politics A Conceptual Approach, Ontario: Nelson canada, 1988, P. 27; dan Padmo Wahjono, Ilmu Negara, Ind Hill Co, Jakarta, 1996, Hlm. 153

17 Harold J Laski, A Grammar of Politicts, George Allen \& Unwin LTD, London, 1938, P.44

18 Soehino, Ilmu Negara, Liberty, Yogyakarta, 2004, Hlm.121.

19 Lihat pembukaan UUD 1945 dan Pasal 2 Undang-Undang Nomor 10 Tahun 2004 Tentang Pembentukan Peraturan Perundang-undangan.

20 Ibid, Pasal 3 UU No, 10 Tahun 2004.

21 Pasal 1 ayat (2) Amandemen UUD 1945 
5. Adanya lembaga-lembaga negara dan badan-badan pemerintahan yang berfungsi sebagai lembaga legislatif (MPR : DPR-DPD), eksekutif (Presiden), yudikatif (Mahkamah Agung dan Mahkamah Konstitusi), pengawasan hakim (Komisi Yudisial), pengawas keuangan negara (BPK), penyelenggara pemilihan umum (KPU), penjaga pertahanan dan keamanan (TNI-Polri), Pembantu Presiden (Menteri-Menteri), Penyelenggara Pemerintahan Daerah (Kepala Daerah dan DPRD), dan Bank Sentral.

6. Memberikan jaminan dan perlindungan terhadap Hak Asasi Manusia; ${ }^{22}$

7. Menormatifkan asas-asas hukum sebagai acuan imperatif lembaga legislatif dan eksekutif di tingkat Pusat maupun Daerah dalam membentuk peraturan perundangundangan yang baik. ${ }^{23}$

8. Adanya jenis dan hierarkhi peraturan perundang-undangan ${ }^{24}$ mempunyai kekuatan hukum mengikat sepanjang diperintahkan oleh peraturan perundang-undangan yang lebih tinggi.

Bersumber dari kedaulatan rakyat, kedaulatan hukum dan kedaulatan Negara, maka dapat diformulasikan berbagai bentuk dan hierarkhi kewenangan atau wewenang untuk menyelanggarakan urusan pemerintahan dan pembangunan. H.D. Stout menyatakan : "Bevoegdheid is een begrip uit het bestuurkke organisatierecht, wat kan worden omschreven als het geheel van regels dat betrekking heeft op de verkrilging en uitoefening van bestuursrechtelijke bevoegdheden door publiekrechtelijke rechtssubjecten in het bestuursrechtelijke rechtsverkeer". ${ }^{25}$ Dari pendapat Stout ini, menunjukkan, bahwa wewenang merupakan pengertian yang berasal dari hukum organisasi pemerintahan, yang dapat dijelaskan sebagai keseluruhan aturan-aturan yang berkenaan dengan perolehan dan penggunaan wewenang pemerintahan oleh subjek hukum publik di dalam hubungan hukum publik.

Berikutnya menurut F.P.C.L. Tonnaer : "Overheidsbevoegdheid wordt in dit verband opgevat als het vermogen om positief recht vast te stellen en aldus rechtsbetrekkingen tussen burgers onderling en tussen overheid en te scheppeel". ${ }^{26}$ Artinya, kewenangan pemerintah dalam kaitan ini dianggap sebagai kemampuan untuk melaksanakan hukum positif, dan dengan begitu, dapat diciptakan hubungan hukum antara pemerintah dengan warga negara.

Kemudian F.A.M. Stroink dan J.G. Steenbeek menyatakan : "Het begrip bevoegdheid is dan ook een kernbegrip in het staats-en administratief recht" (bahwa kewenangan merupakan konsep inti dalam hukum tata negara dan hukum administrasi). ${ }^{27}$ Bahwa di dalam kewenangan, terkandung hak dan kewajiban. Hal ini juga dikemukakan oleh $\mathrm{P}$. Nicolai : "Het vermogen tot het verrichten van bepaalde

2 Pasal 28A s.d. Pasal 28 J Amandemen UUD 1945.

23 Pasal 5 UU No. 10 Tahun 2004.

24 Ibid, UU No. 10 Tahun 2004, Pasal 7 ayat (1) : Jenis dan hierarkhi peraturan perundang-undangan terdiri atas : 1.Undang-Undang Dasar Negara Republik Indonesia Tahun 1945; 2.UndangUndang/Peraturan Pemerintah Pengganti Undang-Undang; 3.Peraturan Pemerintah; 4.Peraturan Presiden; dan 5.Peraturan Daerah.

25 H.D. Stout, de Betekenissen van de Wet, W.E.J. Tjeenk Willink Zwolw, 1994, P, 102.

26 F.P.C.L. Tonnaer, Legaal Besturen; Het Legalheitsbeginsel, Toetssteen of Struikelblok?, Tulisan dalam Bestuur en Norm, Bundel Opstellen Opgedragen aan R. Crince Le Roy, Kluwer-Deventer, 1986, P. 265.

27 F.A.M. Stroink en J.G. Steenbeek, Inleiding in het Staats-en Administratief Rech. Alphen aan den Rijn: Samson H.D.Tjeenk Willink, 1985, P. 26. 
rechtshandelingen (handelingen die op rechtsgevolg gericht zijn en dus ertoe strekken dat bepaalde rechtsgevolgen onstaan of teniet gaan). Een recht houdt in de (rechtens gegeven) vrijheid cm een bepaalde feitekke handeling te verrichten ofna te laten, of de (rechtens gegeven) aanspraak op het verrichten van een handeling door een ander. Een plicht impliceert een verplichting ont een bepaalde handeling te verrichten of na te laten". ${ }^{28}$

Selain itu, Bagir Manan berpendapat bahwa dalam bahasa hukum wewenang tidak sama dengan kekuasaan (macht). Kekuasaan hanya menggambarkan hak untuk berbuat atau tidak berbuat. Sedangkan di dalam hukum, wewenang sekaligus berarti hak dan kewajiban (rechten en plichten). Dalam kaitannya dengan otonomi daerah, hak mengandung pengertian kekuasaan untuk mengatur sendiri (zelfregelen) dan mengelola sendiri (zelfbesturen), sedangkan kewajiban secara horizontal berarti kekuasaan untuk menyelenggarakan pemerintahan sebagaimana mestinya. Vertikal berarti kekuasaan untuk menjalankan pemerintahan dalam satu tertib ikatan pemerintahan negara secara keseluruhan. ${ }^{29}$

Sejalan dengan pendapat Bagir Manan tersebut, R.J.H.M. Huisman menyatakan: "Een bestuursorgaan kan zich geen bevoegdheid toeeigenen. Slechts de wet kan bevoegdheden verlenen. De wetgever kan een bevoegdheid met alleen attribueren aan een bestuursorgaan, maar ook aan ambtenaren (bijvoorbeeld belastinginspecteurs, inspecteur voor het milieu enz.) of aan speciale colleges (bijvoorbeeld de kiesraad, de pachtkamer), of zelfs aan privaatrechtekke rechtspersonen". ${ }^{30}$

Simpulan yang dapat ditarik dari pendapat pakar hukum di atas bahwa kewenangan hakikatnya bersumber dari kekuasaan negara yang diatur berdasarkan konstitusi atau peraturan perundang-undangan. Kemudian dimaknakan sebagai kewenangan/wewenang formal (formal authority) dan difungsikan untuk menyelenggarakan tugas-tugas negara, pemerintahan dan pembangunan guna mencapai tujuan negara sesuai ruang lingkup dan substansi urusannya.

Selanjutnya, dalam doktrin hukum administrasi dikenal tiga cara pokok perolehan wewenang, yaitu : ${ }^{31}$

1. Atribusi : Kewenangan asli yang bersumber langsung dari pemberian wewenang oleh Pembentuk Undang Undang Dasar ataupun Pembentuk Undang Undang kepada Lembaga Negara, Badan-badan Pemerintahan, atau Pejabat Negara Pemerintahan untuk melaksanakan urusan negara/pemerintahan tertentu. Tanggung jawab pelaksanaan kewenangan yang diatribusikan tersebut sepenuhnya berada pada pemegang kewenangan.

28 P. Nicolai, et. al., Bestuurecht, Amsterdam, 1994, P. 4.

29 Bagir Manan, Wewenang Provinsi, Kabupaten, dan Kota dalam Rangka Otonomi Daerah, Makalah pada Seminar Nasional, Fakultas Hukum Unpad, Bandung, 13 Mei 2000, hlm. 1-2.

30 R.J.H.M. Huisman, Algemeen Bestuursrecht, een Inlediding, Amsterdam : Kobra, tt, P. 7. Lihat pula pendapat C.J.N. Versteden, Inleiding Algemenn Bestuursrecht, Samson H.D. Tjeenk Willink, Alphen aan den Rijn, 1984, P. 42. Kemudian P. de Haan, et. al., Bestuursreht in de Sociale Rechtsstaat. Deel 1, Kluwer Deventer, 1986, P. 9 yang menyatakan : "overheidsbeveegdheden komen niet uit de lucht vallen, zij worden door het recht genormeerd" (wewenang pemerintah tidak jatuh dari langit, tetapi ditentukan oleh hukum).

31 Philipus M.Hadjon, Fungsi Normatif Hukum Administrasi Dalam Mewujudkan Pemerintahan Yang Bersih, Naskah pidato peresmian penerimaan jabatan Guru Besar dalam Ilmu Hukum, Fakultas Hukum Universitas Airlangga, Surabaya, 10 Oktober 1994, Hlm. 9, 48,49,95. 
2. Delegasi : Merupakan penyerahan kewenangan dari Badan, Lembaga, atau Pejabat Tata Usaha Negara yang satu (delegans) kepada Badan/ Lembaga/Pejabat Tata Usaha Negara lainnya untuk melaksanakan urusan tertentu dengan konsekuensi tanggung jawab pelaksanaan wewenang itu berada sepenuhnya kepada penerima delegasi (delegataris);

3. Mandat : Suatu pelimpahan kewenangan (kuasa) sementara dari Pejabat Tata Usaha Negara Atasan atau Sederajat (Mandans) kepada Pejabat Tata Usaha Negara Bawahan atau Sederajat (Mandataris) untuk bertindak atas nama pemberi kuasa (Mandans) melaksanakan urusan tertentu, di mana tanggung jawab pelaksanaan wewenang tersebut tetap berada pada pemberi mandat (Mandans).

\section{B. Kewenangan Pengelolaan Kawasan Perbatasan}

Lahirnya Undang-Undang Nomor 43 Tahun 2008 tentang Wilayah Negara, pada prinsipnya sudah memberikan kepastian hukum yang semakin kuat terhadap eksistensi wilayah Negara Kesatuan Republik Indonesia yang diamanatkan Pasal 25A Undang-Undang Dasar 1945. Sebagai negara kepulauan yang berciri nusantara, maka Indonesia mempunyai yurisdiksi penuh di dalam wilayahnya dan memiliki hak-hak berdaulat di luar wilayah kedaulatannya untuk dikelola dan dimanfaatkan sebesarbesarnya bagi kemakmuran rakyat Indonesia. Karena itu, makna wilayah negara sebagaimana dimaksud dalam Undang-Undang Dasar 1945, hakikatnya menganut sistem :

1. Pengaturan suatu Pemerintahan negara Indonesia yang melindungi segenap bangsa Indonesia dan seluruh tumpah darah Indonesia;

2. Pemanfaatan bumi, air, dan udara serta kekayaan alam yang terkandung di dalamnya untuk sebesar-besarnya kemakmuran rakyat;

3. Desentralisasi pemerintahan kepada daerah-daerah besar dan kecil yang bersifat otonom dalam bingkai Negara Kesatuan Republik Indonesia; dan

4. Kesejahteraan sosial bagi seluruh rakyat Indonesia. ${ }^{32}$

Substansi pokok yang diatur dalam Undang-Undang Nomor 43 Tahun 2008 tentang Wilayah Negara, intinya sebagai berikut : ${ }^{33}$

1. Ruang lingkup Wilayah Negara meliputi wilayah daratan, wilayah perairan pedalaman, perairan kepulauan, laut teritorial, dasar laut, dan tanah di bawahnya, serta ruang udara di atasnya termasuk seluruh sumber kekayaan yang terkandung di dalamnya.

2. Hak-hak berdaulat Negara Republik Indonesia di Zona Ekonomi Eksklusif dan Landas Kontinen serta hak pengawasan di Zona Tambahan.

3. Kewenangan Pemerintah melakukan pengaturan pengelolaan dan pemanfaatan wilayah negara serta Kawasan Perbatasan.

4. Kelembagaan yang diberi kewenangan untuk melakukan penanganan Kawasan Perbatasan. Unsur keanggotaan kelembagaan ini berasal dari unsur Pemerintah dan Pemerintah Daerah mengingat posisi strategis wilayah perbatasan terkait dalam hal

32 Penjelasan Umum Undang-Undang Nomor 43 Tahun 2008 tentang Wilayah Negara.

33 Ibid. 
seperti kedaulatan negara, keutuhan wilayah, penegakan hukum dan kesejahteraan rakyat.

5. Keikutsertaan masyarakat dalam menjaga dan mempertahankan Wilayah Negara termasuk Kawasan Perbatasan.

6. Larangan dan sanksi bagi setiap orang yang melakukan pelanggaran terkait dengan Wilayah Negara dan batas-batasnya.

Meskipun berdasarkanPasal 9, Pasal 10, Pasal 11, dan Pasal 12 UU No. 43 Tahun 2008 telah diatur kewenangan Pemerintah, Pemerintah Provinsi dan Pemerintah Kabupaten/Kota dalam mengelola Wilayah Negara dan Kawasan Perbatasan, namun berdasarkan Pasal 13 penjabarannya tetap akan diatur lebih lanjut dengan Peraturan Pemerintah. Pada saat ini, peraturan pemerintah tersebut masih belum terbentuk (dalam proses penyusunan). Pengaturan ini bersifat imperatif yang apabila tidak diwujudkan tentunya akan memiliki dampak yuridis tersendiri. Jika dicermati kewenangan Pemerintah, Pemerintah Provinsi dan Pemerintah Kabupaten/Kota dalam melakukan pengaturan pengelolaan dan pemanfaatan wilayah negara serta Kawasan Perbatasan, berdasarkan Pasal 10, Pasal 11, dan Pasal 12 UU No. 43 Tahun 2008, maka diperoleh gambaran umum sebagai berikut :

1. Kewenangan Pemerintah

Berdasarkan Pasal 10 UU No. 43 Tahun 2008, kewenangan Pemerintah dalam mengatur pengelolaan dan pemanfaatan Wilayah Negara dan Kawasan Perbatasan, adalah terfokus dalam :

a. menetapkan kebijakan pengelolaan dan pemanfaatan Wilayah Negara dan Kawasan Perbatasan;

b. mengadakan perundingan dengan negara lain mengenai penetapan Batas Wilayah Negara sesuai dengan ketentuan peraturan perundang-undangan dan hukum internasional;

c. membangun atau membuat tanda Batas Wilayah Negara;

d. melakukan pendataan dan pemberian nama pulau dan kepulauan serta unsur geografis lainnya;

e. memberikan izin kepada penerbangan internasional untuk melintasi wilayah udara teritorial pada jalur yang telah ditentukan dalam peraturan perundangundangan;

f. memberikan izin lintas damai kepada kapal-kapal asing untuk melintasi laut teritorial dan perairan kepulauan pada jalur yang telah ditentukan dalam peraturan perundang-undangan;

g. melaksanakan pengawasan di zona tambahan yang diperlukan untuk mencegah pelanggaran dan menghukum pelanggar peraturan perundang-undangan di bidang bea cukai, fiskal, imigrasi, atau saniter di dalam Wilayah Negara atau laut teritorial;

h. menetapkan wilayah udara yang dilarang dilintasi oleh penerbangan internasional untuk pertahanan dan keamanan;

i. membuat dan memperbarui peta Wilayah Negara dan menyampaikan-nya kepada Dewan Perwakilan Rakyat sekurang-kurangnya setiap 5 (lima) tahun sekali; dan

j. menjaga keutuhan, kedaulatan, dan keamanan Wilayah Negara serta Kawasan Perbatasan. 
Selain kewenangan tersebut di atas, Pemerintah juga berkewajiban menetapkan biaya pembangunan Kawasan Perbatasan dan dapat menugasi pemerintah daerah untuk menjalankan kewenangannya dalam rangka tugas pembantuan sesuai dengan peraturan perundang-undangan.

2. Kewenangan Pemerintah Provinsi

Kewenangan Pemerintah Provinsi dalam pengelolaan Wilayah Negara dan Kawasan Perbatasan menurut Pasal 11 UU No. 43 Tahun 2008 adalah :

a. melaksanakan kebijakan Pemerintah dan menetapkan kebijakan lainnya dalam rangka otonomi daerah dan tugas pembantuan;

b. melakukan koordinasi pembangunan di Kawasan Perbatasan;

c. melakukan pembangunan Kawasan Perbatasan antar-pemerintah daerah dan/atau antara pemerintah daerah dengan pihak ketiga; dan

d. melakukan pengawasan pelaksanaan pembangunan Kawasan Perbatasan yang dilaksanakan Pemerintah Kabupaten/Kota.

Dalam rangka melaksanakan kewenangan tersebut Pemerintah Provinsi juga berkewajiban menetapkan biaya pembangunan Kawasan Perbatasan.

3. Kewenangan Pemerintah Kabupaten/Kota

Berdasarkan Pasal 12 UU No. 43 Tahun 2008 Pemerintah Kabupaten/Kota dalam pengelolaan Wilayah Negara dan Kawasan Perbatasan, Pemerintah Kabupaten/Kota, berwenang :

a. melaksanakan kebijakan Pemerintah dan menetapkan kebijakan lainnya dalam rangka otonomi daerah dan tugas pembantuan;

b. menjaga dan memelihara tanda batas;

c. melakukan koordinasi dalam rangka pelaksanaan tugas pembangunan di Kawasan Perbatasan di wilayahnya; dan

d. melakukan pembangunan Kawasan Perbatasan antar-pemerintah daerah dan/atau antara pemerintah daerah dengan pihak ketiga.

Dalam rangka melaksanakan kewenangan tersebut di atas, Pemerintah Kabupaten/Kota juga berkewajiban menetapkan biaya pembangunan Kawasan Perbatasan.

4. Tugas Badan Pengelola

Selanjutnya, jika dicermati ketentuan Pasal 14 s.d. Pasal 17 UU No. 43 Tahun 2008, maka terdapat tugas pengelolaan Batas Wilayah Negara dan Kawasan Perbatasan yang diatribusikan kepada Badan Pengelola Nasional dan Badan Pengelola Daerah. Kedua badan ini memiliki karaktristik sebagaimana tersebut di bawah ini :

a. Bahwa untuk mengelola Batas Wilayah Negara dan mengelola Kawasan Perbatasan pada tingkat pusat dan daerah, Pemerintah dan pemerintah daerah membentuk Badan Pengelola Nasional dan Badan Pengelola Daerah. ${ }^{34}$

b. Badan Pengelola Nasional dipimpin oleh seorang kepala badan yang bertanggung jawab kepada Presiden sesuai dengan kewenangannya. ${ }^{35}$ Kedudukan, tugas, fungsi, dan susunan organisasi, serta tata kerja Badan

34 Pasal 14 ayat (1) UU No. 43 Tahun 2008 tentang Wilayah Negara.

35 Ibid, Pasal 14 Ayat (2). 
Pengelola dan sekretariat tetap di tingkat pusat diatur dengan Peraturan Presiden. ${ }^{36}$

c. Badan Pengelola Daerah dipimpin oleh seorang kepala badan yang bertanggung jawab kepada Kepala Daerah sesuai dengan kewenangannya. ${ }^{37}$ Kedudukan, tugas, fungsi, dan susunan organisasi, serta tata kerja Badan Pengelola dan sekretariat tetap di tingkat daerah diatur dengan Peraturan Daerah. ${ }^{38}$

d. Keanggotaan Badan Pengelola berasal dari unsur Pemerintah dan pemerintah daerah yang terkait dengan perbatasan Wilayah Negara. ${ }^{39}$

e. Badan Pengelola bertugas: (a) menetapkan kebijakan program pembangunan perbatasan; (b) menetapkan rencana kebutuhan anggaran; (c) mengoordinasikan pelaksanaan; dan (d) melaksanakan evaluasi dan pengawasan. ${ }^{40}$ Namun pelaksana teknis pembangunan dilakukan oleh instansi teknis sesuai dengan tugas pokok dan fungsinya. ${ }^{41}$

f. Hubungan kerja antara Badan Pengelola nasional dan Badan Pengelola daerah merupakan hubungan koordinatif. ${ }^{42}$

Dalam melaksanakan tugasnya, Badan Pengelola dibantu oleh sekretariat tetap yang berkedudukan di kementerian yang tugas dan tanggung jawabnya di bidang pemerintahan dalam negeri. ${ }^{43}$

5. Peran Serta Masyarakat

Peran serta masyarakat dalam pengelolaan Kawasan Perbatasan juga diatur berdasarkan Pasal 19 UU No. 43 Tahun 2008 dalam bentuk : (a) mengembangkan pembangunan Kawasan Perbatasan; dan (b) menjaga serta mempertahankan Kawasan Perbatasan. Peran serta masyarakat tersebut dilaksanakan sesuai dengan ketentuan peraturan perundang-undangan.

Jika ketiga konsep kewenangan di atas diaplikasikan pada pengaturan kewenangan pemerintah, kewenangan pemerintah provinsi, kewenangan pemerintah kabupaten, tugas Badan Nasional Pengelola Perbatasan dan Badan Pengelola Perbatasan di daerah dalam pengelolaan pembangunan kawasan perbatasan Indonesia, sebagaimana diatur dalam Undang-Undang Nomor 43 Tahun 2008 tentang wilayah Negara Jo Peraturan Presdien Nomor 12 Tahun 2010 tentang Badan Nasional Pengelola Perbatasan (BNPP), maka dapat dikategorikan sebagai kewenangan atribusi.

Sungguhpun demiikian, pelaksanaan kewenangan tersebut haruslah dilakukan secara terkoordinatif, apalagi menurut Peraturan Presiden Nomor 12 Tahun 2010 tentang Badan Nasional Pengelola Perbatasan (BNPP), tidak ditentukan secara tegas apakah BNPP memiliki kedudukan yang sederajat dengan Kementerian Negara ataupun Lembaga Pemerintah Non Kementerian. Peraturan Presiden tersebut hanya menentukan :

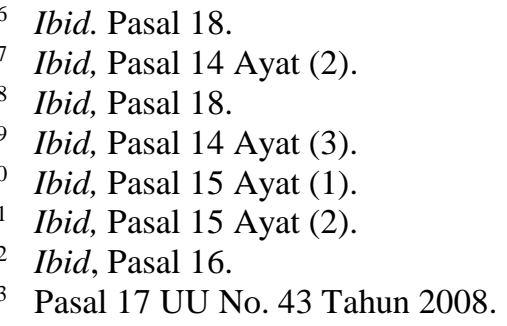


a. BNPP dipimpin oleh seorang Kepala Badan yang berkedudukan di bawah dan bertanggung jawab kepada Presiden (Pasal 2).

b. BNPP mempunyai tugas menetapkan kebijakan program pembangunan perbatasan, menetapkan rencana kebutuhan anggaran, mengoordinasi-kan pelaksanaan, dan melaksanakan evaluasi dan pengawasan terhadap pengelolaan Batas Wilayah Negara dan Kawasan Perbatasan (Pasal 3)

c. Untuk melaksanakan tugas sebagaimana dimaksud dalam Pasal 3, BNPP menyelenggarakan fungsi:

1) Penyusunan dan penetapan rencana induk dan rencana aksi pembangunan Batas Wilayah Negara dan Kawasan Perbatasan;

2) Pengoordinasian penetapan kebijakan dan pelaksanaan pembangunan, pengelolaan serta pemanfaatan Batas Wilayah Negara dan Kawasan Perbatasan;

3) Pengelolaan dan fasilitasi penegasan, pemeliharaan dan pengamanan Batas Wilayah Negara;

4) Inventarisasi potensi sumber daya dan rekomendasi penetapan zona pengembangan ekonomi, pertahanan, sosial budaya, lingkungan hidup dan zona lainnya di Kawasan Perbatasan;

5) Penyusunan program dan kebijakan pembangunan sarana dan prasarana perhubungan dan sarana lainnya di Kawasan Perbatasan;

6) Penyusunan anggaran pembangunan dan pengelolaan Batas Wilayah Negara dan Kawasan Perbatasan sesuai dengan skala prioritas;

7) Pelaksanaan, pengendalian dan pengawasan serta evaluasi dan pelaporan pelaksanaan pembangunan dan pengelolaan Batas Wilayah Negara dan Kawasan Perbatasan.

Kemudian berdasarkan Pasal 6 ditentukan susunan keanggotaan BNPP terdiri atas:

a. Ketua Pengarah : Menteri Koordinator Bidang Politik, Hukum dan Keamanan.

b. Wakil Ketua Pengarah I : Menteri Koordinator Bidang Perekonomian.

c. Wakil Ketua Pengarah II : Menteri Koordinator Kesejahteraan Rakyat

d. Kepala BNPP : Menteri Dalam Negeri

e. Anggota : (1) Menteri Luar Negeri; (2) Menteri Pertahanan;

(3) Menteri Hukum dan Hak Asasi Manusia; (4) Menteri Keuangan; (5) Menteri

Pekerjaan Umum; (7) Menteri Perhubungan; (8) Menteri Kehutanan; (9) Menteri

Kelautan dan Perikanan; (10) Menteri Perencanaan Pembangunan

Nasional/Kepala Badan Perencanaan Pembangunan Nasional; (11) Menteri

Pembangunan Daerah Tertinggal; (12) Panglima Tentara Nasional Indonesia;

(13) Kepala Kepolisian Negara Republik Indonesia; (14) Kepala Badan Intelijen

Negara; (15) Kepala Badan Koordinasi Survei dan Pemetaan Nasional; (16)

Gubernur Provinsi terkait.

Mencermati tugas, susunan kedudukan dan keanggotaan Badan Nasional Pengelola Perbatasan di atas, memperlihatkan eksistensinya lebih tepat bila disebut sebagai Badan Koordinasi Pengelola Perbatasan daripada Lembaga Pemerintah Non Departemen (Kementerian) yang bersifat mandiri, sebagaimana diatur Keputusan Presiden Nomor 103 Tahun 2001 Tentang Kedudukan, Tugas, Fungsi, Kewenangan, 
Susunan Organisasi, dan Tata Kerja Lembaga Pemerintah Non Departemen, Jo Perubahannya Keputusan Presiden Nomor 12 Tahun 2002. ${ }^{44}$

Kenyataan tersebut diperkuat oleh ketentuan Pasal 17 Keputusan Presiden Nomor 12 Tahun 2010 yang menentukan bahwa dalam penyelenggaraan tugas dan fungsinya, BNPP melakukan koordinasi dengan badan pengelola perbatasan di tingkat daerah, meliputi pembinaan, fasilitasi dan pengawasan. Sedangkan penyelenggaraan tugas dan fungsi badan pengelola perbatasan di daerah dikoordinasi oleh Gubernur dalam kedudukannya sebagai wakil Pemerintah dan anggota BNPP. Selain itu tata cara hubungan kerja antara BNPP dengan badan pengelola perbatasan di daerah diatur oleh Kepala BNPP.

Pada saat ini, BNPP sedang menyusun Rencana Induk dan Rencana Aksi Pembangunan Batas Wilayah Negara dan Kawasan Perbatasan, sebagiaimana ditentukan Pasal 4 Peraturan Presiden Nomor 12 Tahun 2010 tentang BNPP, yang diprediksikan dapat diselesaikan dalam tahun 2011. Sementara Kementerian Negara Perencanaan Pembangunan Nasional/Badan Perencanaan Pembangunan Nasional sudah selesai menerbitkan dokumen Rencana Induk Pengelolaan Batas Wilayah Negara Dan Kawasan Perbatasan Tahun 2011-2014, sebagaimana diterbitkan PT. Pillar Pusaka Inti.

Persoalannya, apakah yang akan dijadikan acuan pelaksanaan pembangunan kawasan perbatasan Rencana Induk bentukan BAPPENAS atau Rencana Induk dan Rencana Aksi bentukan BNPP. Hal ini, mencerminkan belum sinkronnya kewenangan penyusunan Rencana Induk dan Rencana Aksi Pembangunan Batas Wilayah Negara dan Kawasan Perbatasan, setelah berlakunya Undang-Undang Nomor 43 Tahun 2008 dan Peraturan Presiden Nomor 12 Tahun 2010. Tegasnya masih ada dua lembaga yang berkewenangan menyusun Rencana Induk dan Rencana Aksi Pembangunan Batas Wilayah Negara dan Kawasan Perbatasan.

Apalagi untuk menyusun dan menetapkan Rencana Induk dan Rencana Aksi tersebut juga masih harus disesuaikan dengan substansi urusan dan kewenangan kelembagan pusat dan daerah yang terkait dengan penyelenggaraan urusan pemerintahan daerah dan perencanaan pembangunan nasional, yaitu :

44 Menurut Keputusan Presiden ini, Lembaga Pemerintah Non Departemen dimaksud adalah : 1. Lembaga Administrasi Negara disingkat LAN; 2. Arsip Nasional Republik Indonesia disingkat ANRI; 3. Badan Kepegawaian Negara disingkat BKN; 4. Perpustakaan Nasional Republik Indonesia disingkat PERPUSNAS; 5. Badan Perencanaan Pembangunan Nasional disingkat BAPPENAS; 6. Badan Pengendalian Dampak Lingkungan disingkat BAPEDAL; 8. Badan Pusat Statistik disingkat BPS; 9. Badan Standardisasi Nasional disingkat BSN; 10. Badan Pengawas Tenaga Nuklir disingkat BAPETEN; 11. Badan Tenaga Nuklir Nasional disingkat BATAN; 12. Badan Intelijen Negara disingkat BIN; 13. Lembaga Sandi Negara disingkat LEMSANEG; 14. Badan Urusan Logistik disingkat BULOG; 15. Badan Koordinasi Keluarga Berencana Nasional disingkat BKKBN; 16. Lembaga Penerbangan Antariksa Nasional disingkat LAPAN; 17. Badan Koordinasi Survei dan Pemetaan Nasional disingkat BAKOSURTANAL; 18. Badan Pengawasan Keuangan dan Pembangunan disingkat BPKP; 19. Lembaga Ilmu Pengetahuan Indonesia disingkat LIPI; 20. Badan Pengkajian dan Penerapan Teknologi disingkat BPPT; 21. Badan Koordinasi Penanaman Modal disingkat BKPM; 22. Badan Pertanahan Nasional disingkat BPN; 23. Badan Pengawas Obat dan Makanan disingkat BPOM; 24. Lembaga Informasi Nasional disingkat LIN; 25. Lembaga Ketahanan Nasional disingkat LEMHANNAS; 26. Badan Pengembangan Kebudayaan dan Pariwisata disingkat BP BUDPAR; 27. Badan Meteorologi dan Geofisika disingkat BMG. 
a. Undang-Undang Nomor 32 tahun 2004 tentang Pemerintah Daerah, terutama berkenaan dengan substansi : (1) Pasal 9 mengenai penetapan kawasan khusus dan fungsi pemerintahan tertentu untuk perdagangan bebas dan/atau pelabuhan bebas yang ditetapkan dengan undang-undang; (2) Pasal 13 dan Pasal 14 tentang penyelenggaraan urusan desentralisasi baik urusan wajib maupun pilihan oleh Pemerintah Provinsi dan Kabupaten di kawasan perbatasannya dengan negara tetangga.

b. Undang-Undang Nomor 25 Tahun 2004 Tentang Sistem Perencanaan Pembangunan Nasional, terkait dengan kewenangan BAPPEDA Provinsi dan Kabupaten yang memiliki kewenangan atribusi untuk menyusun RPJP, RPJM dan RKP Daerah, yang juga dapat mencakup kawasan perbatasan.

c. Undang-Undang Nomor 26 Tahun 2007 Tentang Penataan Ruang. Di mana berdasarkan Pasal 10 dan Pasal 11 baik Pemerintah Provinsi maupun Kabupaten/Kota berwenang dalam melakukan penyelenggaraan penataan ruang yang meliputi pengaturan, pembinaan, pengawasan, perencanaan, dan pelaksanaannya, termasuk di kawasan perbatasan dengan negara tetangga.

d. Undang-Undang sektoral lainnya yang menjadi acuan Departemen, Lembaga Pemerintah Non Departemen dalam menyusun Rencana Strategis Kementerian/Lembaga (Renstra-KL) dan RKP Departemen/LPND yang juga harus dipadukan dengan RPJM dan RKP Badan Pengelola Nasisonal maupun Badan Pengelola Provinsi dan Kabuten/Kota.

Keempat persoalan di atas layak dicermati dalam proses penyusunan rencana dan pelaksanaan rencana pembangunan di kawasan perbatasan Indonesia dengan Negara tetangga, agar benar-benar terangkat harkat dan martabat rakyat Indonesia di Kawasan perbatasan dalam visi menjadikan kawasan perbatasan sebagai beranda depan negara Indonesia.

Kemudian, menurut Pasal 18 UU No. 43 Tahun 2008, Kedudukan, tugas, fungsi, dan susunan organisasi, serta tata kerja Badan Pengelola dan sekretariat tetap di tingkat daerah diatur dengan Peraturan Daerah. Karena itu bagi Pemerintah Daerah Provinsi yang sebelum diterbitkannya UU No. 43 Tahun 2008 telah membentuk Badan Pengelola Daerah Kawasan Perbatasan, tentunya wajib merevisi atau menggantinya sesuai ketentuan UU No. No. 43 Tahun 2008.

\section{KESIMPULAN}

Secara normatif, pengaturan kewenangan pengelolaan pembangunan kawasan perbatasan Indonesia dengan negara tetangga berdasarkan Undang-Undang Nomor 43 Tahun 2008 tentang Wilayah Negara dan Peraturan Presiden Nomor 12 Tahun 2010 tentang BNPP dapat dikatakan sudah cukup jelas dan akan mampu mendorong percepatan pelaksanaan pembangunan kawasan perbatasan sebagai beranda depan Negara Kesatuan Republik Indonesia.

Akan tetapi, berhasil tidaknya mewujudkan kesejahteraan rakyat secara kongkret di kawasan perbatasan sangat tergantung pada efektifitas pelaksanaan kewenangan pemerintah, pemerintah provinsi, pemerintah kabupaten/kota, dan badan pengelola dalam menyusun Rencana Induk, Rencana Aksi, Ketersediaan Anggaran, 
Pelaksanaan, Pengawasan dan Evaluasinya secara obyektif, konsekuen, konsisten serta berkesinambungan. 


\section{DAFTAR PUSTAKA}

\section{Literatur :}

BAPPEDA Kalimantan Barat, Pembangunan Kawasan Perbatasan Kalimantan Barat Sarawak Sebagai Beranda Depan NKRI, Pontianak, 2006.

Bagir Manan, 2000. Wewenang Provinsi, Kabupaten, dan Kota dalam Rangka Otonomi

Daerah, Makalah pada Seminar Nasional, Fakultas Hukum Unpad, Bandung.

de Haan, P. et. al., 1986. Bestuursreht in de Sociale Rechtsstaat. Deel 1, Kluwer Deventer.

Dickerson. Mark O. and Thomas Flanagan, 1988. An Introduction to government and politics A Conceptual Approach, Ontario: Nelson Canada.

Huisman, J.H.M. tt. Algemeen Bestuursrecht, een Inlediding, Amsterdam : Kobra.

Jones, Tudor. 2002. Modern Political Thinkers And Ideas An Historical Introduction. London: Routledge.

Lembaga Ketahanan Naioanal,1997. PT. Balai Pustaka - Lemhanas, Jakarta.

Nicolai, P. et. al., 1994. Bestuurecht, Amsterdam.

Padmo Wahjono, 1996. Ilmu Negara, Ind Hill Co, Jakarta.

Philipus M.Hadjon, 1994. Fungsi Normatif Hukum Administrasi Dalam Mewujudkan Pemerintahan Yang Bersih, Naskah pidato peresmian penerimaan jabatan Guru Besar dalam Ilmu Hukum, Fakultas Hukum Universitas Airlangga, Surabaya.

Price, J.H. 1975. Comperative Government, London: Hutchinson \& Co.

Rencana Induk Pengelolaan Batas Wilayah Negara Dan Kawasan Perbatasan, 20112014, Kementerian Perencanaan Pembangunan Nasional/Badan Perencanaan Pembangunan Nasional, PT.Pillar Pusaka Inti, Jakarta, Desember, 2010.

Soehino, 1980. Ilmu Negara, Liberty, Yogyakarta.

Stout, H.D. 1994. de Betekenissen van de Wet, W.E.J. Tjeenk Willink Zwolw.

Stroink, F.A.M. en J.G. Steenbeek, 1985. Inleiding in het Staats-en Administratief Rech. Alphen aan den Rijn: Samson H.D.Tjeenk Willink.

Tonnaer, F.P.C.L. 1986. Legaal Besturen; Het Legalheitsbeginsel, Toetssteen of Struikelblok?, dalam Bestuur en Norm, Bundel Opstellen Opgedragen aan R. Crince Le Roy, Kluwer-Deventer.

Versteden, C.J.N. Inleiding Algemenn Bestuursrecht, Samson H.D. Tjeenk Willink, Alphen aan den Rijn, 1984.

\section{Daftar Perundang-undangan :}

Amandemen UUD 1945.

Undang-Undang Nomor 10 Tahun 2004 Tentang Pembentukan Peraturan Perundangundangan.

Undang-Undang Nomor 43 Tahun 2008 tentang Wilayah Negara.

Peraturan Presiden Nomor 12 Tahun 2010 tentang Badan Nasional Pengelola Perbatasan. 
